\title{
A fragmented environmental state? Analysing spatial compliance patterns for the case of transparency legislation in China
}

\author{
Stefan Brehm ${ }^{1}$ (D) Jesper Svensson ${ }^{2}$
}

Received: 26 May 2017/ Accepted: 6 October 2017/Published online: 6 November 2017

(C) The Author(s) 2017. This article is an open access publication

\begin{abstract}
Do Chinese cities compete for investments with lax environmental law enforcement? The here presented study suggests that this is true for some municipalities but not all of them. Based on data for $126 \mathrm{key}$ environmental protection cities and regional economic hubs between 2010 and 2012 we show that economic decentralization and political centralization both shape spatial patterns of compliance with environmental transparency legislation. Our results give reason to suppose that the Chinese economy moved beyond homogenous preferences for low-cost regulatory arrangements. The emerging jurisdictional interaction is in line with a Tiebout sorting process, where cities compete with diverse factor packages to attract an optimal amount of investments.
\end{abstract}

Keywords China $\cdot$ Environmental governance $\cdot$ Law implementation · Spatial Durbin

JEL Classification H77 $\cdot$ P25 - Q58 · R58

\section{Introduction}

Political and economic objectives during early stages of industrial development often are at odds with a firm regulatory commitment to protect the environment from excessive industrial pollution and resource exploitation (Grossman and Krueger 1991; Stern et al. 1996; Olson 1963). Turning points may be reached when

Stefan Brehm

stefan.brehm@ace.lu.se

1 Centre for East and South East Asian Studies, Lund University, P.O Box 118, 22100 Lund, Sweden

2 School of Geography and the Environment, Oxford University, South Parks Road, Oxford OX1 3QY, UK 
a rising middle-class prepares to organize against vested economic interests (Rock 2002; Tsang and Lee 2013; Foster 2014); when pollution related health problems and human misery begin to destabilize the social and public order (Deng and Yang 2013; Johnson 2013); or when clean technologies become easily and cheaply available (Kemp and Soete 1992; Antle and Heidebrink 1995; Tester and Langridge 2010). The shift towards sustainable production is a slow moving process, which gradually permeates certain sectors or regions. Yet, the technological and institutional change synchronizing ecological preservation and economic development is not inevitable and there are many factors that may enable or constrain this process (Boyd and Folke 2011). From a regulatory perspective one of the most fundamental issues concerns the appropriate level of government overseeing and enforcing environmental standards (Oates and Schwab 1988; Wellisch 1995; Sigman 2014). Centralized regulation can be futile particularly in vast territorial states that feature a high degree of economic, social, and political heterogeneity. By contrast, decentralized regional standards overcome the "one-size-fits-all" problem but at the same time incentivize jurisdictions to compete for mobile capital by lowering environmental standards in a "race-to-the-bottom" (Engel 1996; Levinson 2003).

China is often cited as an example where the devolution of fiscal authority contributed to an unprecedented high-growth period lasting for more than 30 years in concert with large-scale environmental degradation that is threatening the health and livelihood of China's citizens and beyond (Jahiel 1998, 1997; Stern 2004; Kostka and Mol 2013a). The market preserving federalism literature asserts that local governments in China act as economic facilitators because they are allowed to retain the lion's share of resulting tax income (Qian and Weingast 1996; Montinola et al. 1995). At the same time, however, streamlining economic incentives with quasi-federalist structures undermined environmental standards even though regulation in this realm remains the prerogative of the Central Government. Ample regulatory space between vague national laws and detailed local implementation guidelines, for instance, allows local governments to hollow out the spirit and guiding principles of environmental regulation. The literature refers to this implementation gap as "local protectionism" because it is assumed that lower government ranks resist national legislation to protect their own economic interests (Van Rooij 2006; Van Rooij and LO 2010). Local governments might even engage in state corroding activities (Cai and Treisman 2004). For instance, they may assist corporations to circumvent costly national environmental requirements through lax regulation, report false data, cover up for pollution, or grant undefined grace periods.

Yet State and Party organizations remain strictly centralized, which renders local leaders accountable to their superiors (Blanchard and Shleifer 2001). While this system of basic compliance has been discussed widely in terms of economic decision-making (Zhang 2006; Enikolopov and Zhuravskaya 2007; Xu 2011) it was only recently that researchers extended this view into the field of environmental governance. Studies in this vein call for a revalidation or at least stronger differentiation of the central-local dichotomy (Kostka and Mol 2013b; Li and Higgins 2013; Li et al. 2011; Liu et al. 2013). Several regions and cities embarked 
on substantial efforts to initiate an ecological turn around. Factors contributing to this shift are political leadership, intensified civic engagement in environmental matters, more effective institutional arrangements for decentred governance, a stronger emphasize on the rule-of-law, and revised criteria for cadre evaluation. The uneven distribution of incentives and opportunities arising from improving environmental governance may translate into divergent compliance patterns.

On a general note, there is broad agreement that economic development is a decisive factor shaping environmental governance in China. In addition recent case studies bring to the fore idiosyncratic factors facilitating a policy shift where some municipalities take the lead in 'turning green'. Yet little is known how cities shape broader patterns of environmental law enforcement. Does economic decentralisation instigate a green divide among Chines urbanities? Or does political centralisation promote inter-jurisdictional convergence? This study seeks to provide some answers for the case of environmental transparency regulations. We review the literature on environmental governance in China and derive three main hypotheses about emerging spatial enforcement patterns. We deploy a spatial Durbin model to analyse data for 126 key environmental protection cities and regional economic hubs between 2010 and 2012. The results give reason to suppose that municipalities within the same province converge towards similar enforcement levels while nationwide compliance with transparency regulations is becoming increasingly dispersed.

\section{Principles of environmental governance}

Working principles for China's environmental governance regime developed from a command-and control-based system with fixed targets towards a more open management style that seeks to integrate various stakeholder groups and promote sustainable economic development (Carter and Mol 2013). The first environmental protection law of the People's Republic of China was enacted in 1979 and overseen by the National Environmental Protection Agency (NEPA) (He et al. 2012). In 1989 a revised version of the environmental protection law stipulated a sector specific approach (air, water, soil), environmental quality standards, and maximum pollution targets. In 1994 the Chinese government promulgated its Agenda 21 featuring a new take on environmental protection with the aim to develop a political program for sustainable development (He et al. 2012). To this end NEPA was equipped with more administrative competences and renamed State Environmental Protection Agency (SEPA). NGOs and citizens became increasingly involved in environmental protection and a toolbox of financial incentives, emission trading, and environmental liability principles complemented top-down command and control measures (Xie 2011). Another milestone was reached in 2002 with the Cleaner Production Promotion Law indicating a strategic transition from pollution control to prevention (He et al. 2012; Geng et al. 2012). In 2008 SEPA was upgraded from viceministerial rank to the Ministry of Environmental Protection (MEP) (Li and Higgins 2013).

National legislation and the rising political influence of China's environmental bureaucracy reflect changing preferences at the Centre. Yet this new political 
agenda does not blend well with the local bureaucracy's incentives for implementing respective rules and regulations. The main reason behind an apparent conflict between Central and local interests is China's environmental governance regime emulating universal state administrative principles of a vertical command line (tiaotiao) with the Ministry of Environmental Protection at the top and county-level environmental protection bureaux (EPB) at the bottom and a horizontal division (kuaikuai) between the Centre in Beijing and local governments at the provincial, prefectural, county, township, and village level. The MEP is in charge of drafting laws and regulations, planning and formulating targets, as well as overseeing compliance with environmental standards. Local governments are responsible for implementing and financing centrally assigned tasks and responsibilities as well as formulating and coordinating local strategies for environmental protection (Jahiel 1997; Brehm 2013). Incentive structures within this organizational framework have been changing over time.

Local governments often turn a blind eye on corporate environmental misbehaviour because the Chinese fiscal system puts increasing strain on local budgets. Figure 1 depicts how fiscal reforms since the 1980s and in particular the 1993 tax reform shaped an institutional arrangement where expenditures are prone to become localised and income more centralized (Wong and Bird 2008). In the field of environmental protection more than $95 \%$ of expenditures originate from local income sources (Fig. 2). Increasing pressure to attract investments in combination with tightening budgetary constraints creates strong incentives for free-riding. In this context Deng et al. (2012) show for 249 prefecture-level cities in China in 2005 that municipalities cut spending when their neighbours increase them.

With the 11th 5-year-Plan responsibility for fulfilling environmental targets has been handed over from the EPB to local governments, which had a positive impact on environmental policy implementation (Heberer and Senz 2011). Leading Government and Communist Party cadres are evaluated annually upon a previously concluded target responsibility contract defining performance criteria. Targets are categorised as priority-, hard-, or ordinary target. Failing to fulfil a priority target
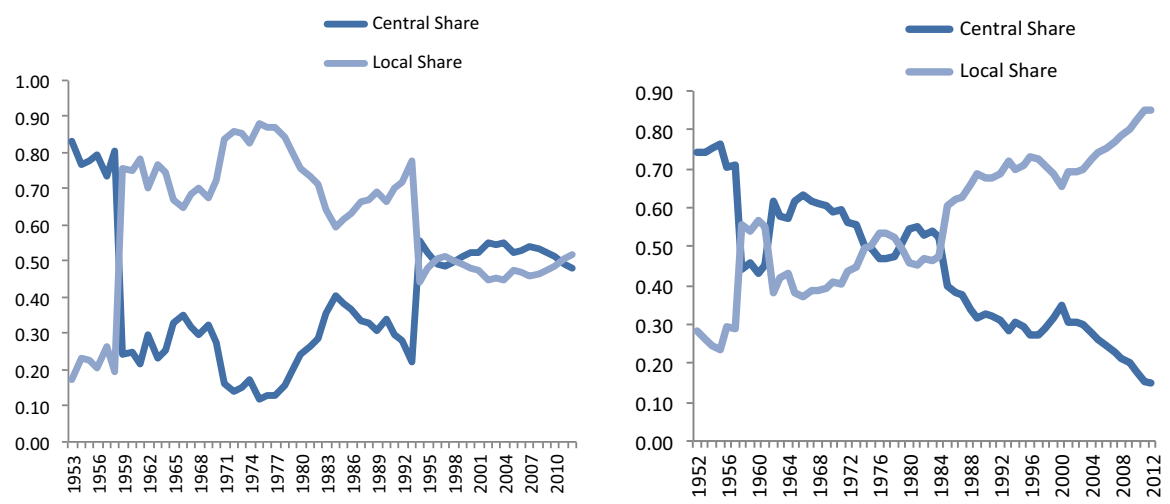

Fig. 1 Central and local share of public expenditures (left) and income (right). Source: Authors' chart based on data from China Statistical Yearbook (various issues) 


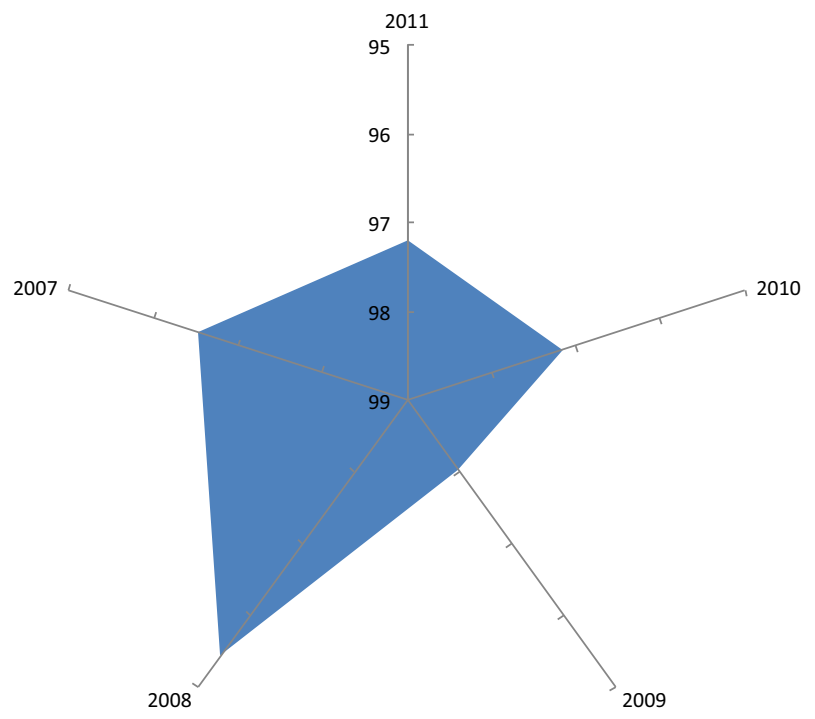

Fig. 2 Local environmental expenditures as a share of total expenditures by year. Source: Authors' calculation based on data from China Statistical Yearbook (various issues)

renders all other achievements invalid. In addition, a favourable evaluation requires to score well in achieving hard targets (Ong 2012). To push for a stricter implementation of national environmental legislation the 11th 5-year Plan elevated environmental targets from ordinary to hard (Wang 2013). But local officials have also become more responsive to environmental issues because pollution constitutes one of the main causes for social unrest (Bloomberg 2013; van Rooij 2010; Wu 2013). Containing protest and petitions in turn is often a priority evaluation target for leading government cadres (Heberer and Trappel 2013). Besides the carrots and sticks of political centralization the Central Government has also launched a row of environmental management programs for stimulating local environmental commitment (Li and Higgins 2013). ${ }^{1}$ Participating in green initiatives or pioneering environmental governance models enhances a local leader's profile and chances to be promoted. What is more, local governments of economically advanced jurisdictions began also to regard a strong focus on environmental concerns as an advantage for attracting (high value-added) investments ( $\mathrm{Li}$ et al. 2011).

On a general note local governments remain accountable to business interests. Yet China's modernized environmental governance system provides also new political visions for economically advanced jurisdictions that are able to frame concern for the environment as a competitive advantage. This observation gives reason to suppose that China passed the point of homogenous preferences for lowcost, lax environmental law enforcement. In the following section we will discuss

\footnotetext{
${ }^{1}$ For instance the Department of Pollution Control and the MEP carry through a project on quantitative examination of comprehensive control of urban environment (QECCUE), the 9th 5-year-plan (1996-2000) introduced the model city for protecting the environment, and SEPA together with the National Bureau of Statistics launched the green gdp accounting program in 2005.
} 
from a theoretical perspective what these diversified incentives mean for changing spatial compliance patterns.

\section{Theory and hypotheses}

\subsection{Theoretical considerations}

China has no federal state order, and the political system is highly centralized. Yet it is widely acknowledged that the devolution of economic decision-making and the prevalent tax-sharing arrangement gives rise to a quasi-fiscal federalist system (Montinola et al. 1995; Jin et al. 2005). In this context empirical research brings to the fore economic incentives as a core component for disciplining local governments (Zhuravskaya 2000). The theoretical literature informing empirical research on China in this vein is often labelled "second generation fiscal federalism" (Weingast 2014). Similar to the first generation, this literature strand evaluates the performance of decentralized systems but instead of assuming a benevolent government it emphasises economic and political incentives. Fiscal federalism research in this context is extensive and controversial as politicians and academics struggle to adapt normative theoretical assumption to the complexity and diversity of real-world fiscal systems. Feng et al. (2013) provide an excellent review of the literature and a discussion against the backdrop of the Chinese experience. For the study at stake it is sufficient to elaborate the free-rider problem in fiscal federalism.

The seminal work of Tiebout (1956) proposed that fiscal autonomy can serve as a disciplining devise because local governments will compete for mobile consumers by offering a mix of public goods. Each jurisdiction adapts its offer until it attracts an optimum amount of residents that is needed to efficiently provide a distinct public service package. It has been argued that the Tiebout sorting mechanism might be less relevant to understand federalist structures in developing countries because local governments rarely have the capacity or incentives to respond to consumer needs (Oates 1993). Successive research, therefore, argued that the Tiebout model is better suited for the sphere of production, i.e., the provision of local factors rather than public goods (Richter 1994). Yet in the context of developing or emerging economies investor preferences might not be diverse enough to allow local governments to target specific demands. Instead all jurisdictions will aim at offering cheap production factors and hence engage in a race-to-the-bottom.

What does this mean for the enforcement of environmental standards? At an early stage of development all jurisdictions stipulate similarly low legal requirements. As industries diversify some jurisdictions will be in the position to raise regulatory ambitions to get rid of polluting factories and instead attract high valueadded service sectors that rely on human capital. 


\subsection{Economic decentralization effect}

In case there is measurable interaction present economic decentralization may promote two different outcomes:

H1a Under relatively homogenous preferences all jurisdictions will offer similar regulatory requirements (race-to-the-bottom hypothesis).

H1b Under relatively heterogeneous preferences jurisdictions will offer diverse regulatory requirements (Tiebout-sorting hypothesis).

\subsection{Political centralization effect}

The above theoretical considerations do not take into account that environmental regulation often is a Central Government task. National oversight may effectively constrain local discretion and mitigate the free-riding problem. In this case we expect municipalities to converge in their enforcement practices:

H2 Under relatively strong top-down regulatory enforcement jurisdictions that are subordinated to the same administration will offer similar regulatory requirements (political centralization hypothesis)

\subsection{Spatial net effect}

Political centralization and economic decentralization may evolve in parallel with an undetermined spatial net effect:

H3a Under homogenous preferences the spatial net effect of political centralization and economic decentralization will be positive.

H3b Under heterogeneous preferences the spatial net effect of political centralization and economic decentralization will be negative given that the latter effect is relatively large.

In the following section we will elaborate how we seek to capture these potentially competing forces and the resulting net effect.

\section{Empirical model, data, and variables}

\subsection{Model}

We use a public factor production function for $i=1 \ldots N$ municipalities in years $t=1 \ldots T$. The public factor provided, $g$, is produced with local government financed input $s$. Each jurisdiction's public factor provision is embedded into a local context. Factors with an impact on $g$ are included in matrix $X$. The basic function hence can be written as $g_{i t}=\zeta s_{i t}+\beta X_{i t}+\varepsilon_{i t}$ where $\zeta$ and $\beta$ represent fixed but unknown elasticities, and $\varepsilon$ are uncorrelated residuals. We augment this basic model 
so that public good provisioning in jurisdiction $i$ depends in addition on spill-over effects in municipalities $j$ with $j \neq i \wedge j=1 \ldots(N-1)$. We consider also the possibility that factors $X$ in jurisdictions $\mathrm{j}$ impact the level of public good provision in municipality $i$. Formally this model is expressed as $g_{i t}=\rho W g_{j t}+\zeta s_{i t}+$ $\beta X_{i t}+W X_{j} \theta+\varepsilon_{i t}$ where $W$ is a $N \times N$ matrix defining spatial neighbourhood, $\rho$ and $\theta$ stand for $N \times 1$ vectors of elasticity that need to be estimated. This spatial Durbin model (SDM) (Anselin 1988), can be simplified to the more known case of a spatial lag model (SAR) if $\theta=0$ or a spatial error model (SEM) if $\theta=-\rho \beta$ (Elhorst 2010).

\subsection{Definitions of proximity}

\section{(a) Spatial proximity}

The first law of geography "Everything is related to everything else, but near things are more related than distant things" (Tobler 1970), establishes the main reason why unbiased results often require to account for spatial interaction. In absence of any previous knowledge about the type and nature of spatial dependence an inverse distance matrix represents a sensible approach to implement the first law of geography. Technically, it is advisable to define a cut-off for an inverse distance matrix to make sure that the correlation between two spatial units converges towards zero (Elhorst 2010). In this context, a distance band will bind row and column sums of the matrix in absolute value before row-standardization. To determine an adequate distance band, we experimented with different cut-off points and report the results in Sect. 5.2.

(b) Economic proximity

With the three main hypotheses presented in Sect. 3 we proposed a theoretical foundation where the spatial net effect is the result of economic decentralization on the one hand, and political centralization on the other. We hypothesized that economic disparities between different regions in China induce a Tiebout sorting process where municipalities offer a 'regulatory package' that they consider suitable for attracting investments. The legal principle 'implement according to local conditions' (yindi zhiyi) provides room for local discretion in this context. Yet, while this line of argument is intriguing and certainly in line with the predictions of the environmental Kuznets Curve it is not necessarily evidence for a Tiebout-sorting mechanism because practically there is very little competition between the most and least developed jurisdictions in a country. Thus, to evaluate the role of economic decentralization we need to observe regulatory response functions among jurisdictions on a comparable development level. To this end we deploy an economic distance matrix where proximity is defined by income quartile. We calculate income as the average p.c. gdp during the sample period. 


\section{(c) Administrative proximity}

Economic decentralization during the 1980s and 1990s induced a shift from the relative importance of vertical command structures (tiaotiao) stretching from Beijing down to local units towards horizontal political coordination (kuaikuai) among provinces, municipalities and counties (Lieberthal and Oksenberg 1988). The provincial Party and Government organization have a key role in mediating guidelines of the Central State and coordinate implementation efforts within their jurisdiction. City leaders are not accountable to their constituencies but to their superiors at the provincial level. Thus, a potential mimicking effect most likely plays out along China's administrative hierarchy. We seek to grasp a potential convergence trend due to political centralization effect with an administrative distance matrix where municipalities of the same province are defined as neighbours.

\subsection{Dependent variable}

For our empirical analysis we look at the MEP's Measures on Open Environmental Information (MOEI), which were promulgated in May 2008. The document states that local governments must disclose information within six areas: environmental laws and regulations, allocation of emission quotas, pollution fees collected, grace periods and exemptions granted outcomes of investigations into public complaints, and corporate violations of environmental regulations. The MOEI represent a typical example of top-down policy making, where local governments do not have any regulatory ownership but at the same time are obliged to implement and finance respective measures. For us this case is of particular interest because two NGOs, the Institute of Public and Environmental Affairs (IPE), and the Natural Resources Defence Council (NRDC) jointed forces to monitor and measure this initiative in 128 cities throughout China. The resulting Pollution Information Transparency Index (PITI) has been published since 2008.

PITI scores represent an aggregate of eight sub-indicators with relative weights ranging between 4 and 28\%. The maximum achievable score is 100 and 60 is defined as the threshold for basic compliance. Table 1 depicts descriptive statistics on the eight subcategories as well as their relative weight in the index calculation. In 2010, 35 out of 126 municipalities were at least basically compliant, but in 2012 the number had declined to 22 . There seems to be a general trend towards enhanced transparency since the average score growth for all categories besides 'results of enforcement campaigns' are positive for the period between 2010 and 2012. Yet there is room for improvement given that Chinese cities stay below $60 \%$ of the respective maximum score; i.e., on average Chinese cities are not even basically compliant with any of the subcategories.

The descriptive statistics in Table 1 indicate that implementation of the Open Environmental Information guidelines is remarkably uneven. In Fig. 3 we depict compliance levels with a choropleth map. The picture emerging suggests that regulatory variation translates into spatial dispersion of law enforcement. The map 
Table 1 Summary statistics (dependent variable)

\begin{tabular}{|c|c|c|c|c|c|c|c|c|}
\hline Variable & Obs. & Mean & $\begin{array}{l}\text { Std. } \\
\text { Dev. }\end{array}$ & Min & Max & Weight & $\begin{array}{l}\text { Average } \\
\text { change } \\
(\%)\end{array}$ & $\begin{array}{l}\text { Average } \\
\text { achievement } \\
(\%)\end{array}$ \\
\hline $\begin{array}{l}\text { Pollution information } \\
\text { transparency index }\end{array}$ & 347 & 39.72 & 16.72 & 12.00 & 85.30 & 100 & 13.83 & 39.72 \\
\hline $\begin{array}{l}\text { Records of enterprise } \\
\text { violations }\end{array}$ & 330 & 9.62 & 5.93 & 0.00 & 28.00 & 28 & 10.91 & 34.34 \\
\hline $\begin{array}{l}\text { Results of "enforcement } \\
\text { campaigns" against } \\
\text { polluting facilities }\end{array}$ & 330 & 4.28 & 1.78 & 0.00 & 7.40 & 8 & -1.39 & 53.50 \\
\hline $\begin{array}{l}\text { Clean production audit } \\
\text { information }\end{array}$ & 331 & 2.98 & 1.54 & 0.00 & 8.00 & 8 & 16.96 & 37.30 \\
\hline $\begin{array}{l}\text { Enterprise environmental } \\
\text { performance ratings }\end{array}$ & 330 & 0.87 & 1.59 & 0.00 & 6.20 & 8 & 11.50 & 10.86 \\
\hline $\begin{array}{l}\text { Disposition of verified } \\
\text { petitions and complaints }\end{array}$ & 330 & 9.23 & 5.88 & 0.00 & 18.00 & 18 & 19.55 & 51.29 \\
\hline $\begin{array}{l}\text { Environmental impact } \\
\text { assessment (EIA) reports } \\
\text { and project completion } \\
\text { approvals }\end{array}$ & 330 & 2.51 & 2.03 & 0.00 & 7.60 & 8 & 11.67 & 31.43 \\
\hline Discharge fee data & 329 & 1.31 & 1.46 & 0.00 & 4.00 & 4 & 27.75 & 32.66 \\
\hline $\begin{array}{l}\text { Response to public } \\
\text { information requests }\end{array}$ & 329 & 9.01 & 6.52 & 0.00 & 18.00 & 18 & 18.41 & 50.04 \\
\hline
\end{tabular}

provides a first indication that environmental law implementation is based on regional clusters rather than nation-wide uniform compliance.

PITI scores only give a glimpse on the patterns of environmental law enforcement in China. It is hard to say whether transparency regulations face similar, more, or less implementation obstacles. Also transparency does not necessarily translate into accountability; a risk that is particularly pronounced in an authoritarian context. Political intervention might also have an influence on how information for this index is collected or presented. Yet given that the PITI by definition rests on visible features it still entails great potential to render enforcement levels observable and comparable.

\subsection{Independent variables}

What factors shape local enforcement of environmental laws in general and transparency regulations in particular? Several literature strands bring to the fore a series of potential influences that we divided into baseline variables, fiscal variables, and economic variables: 


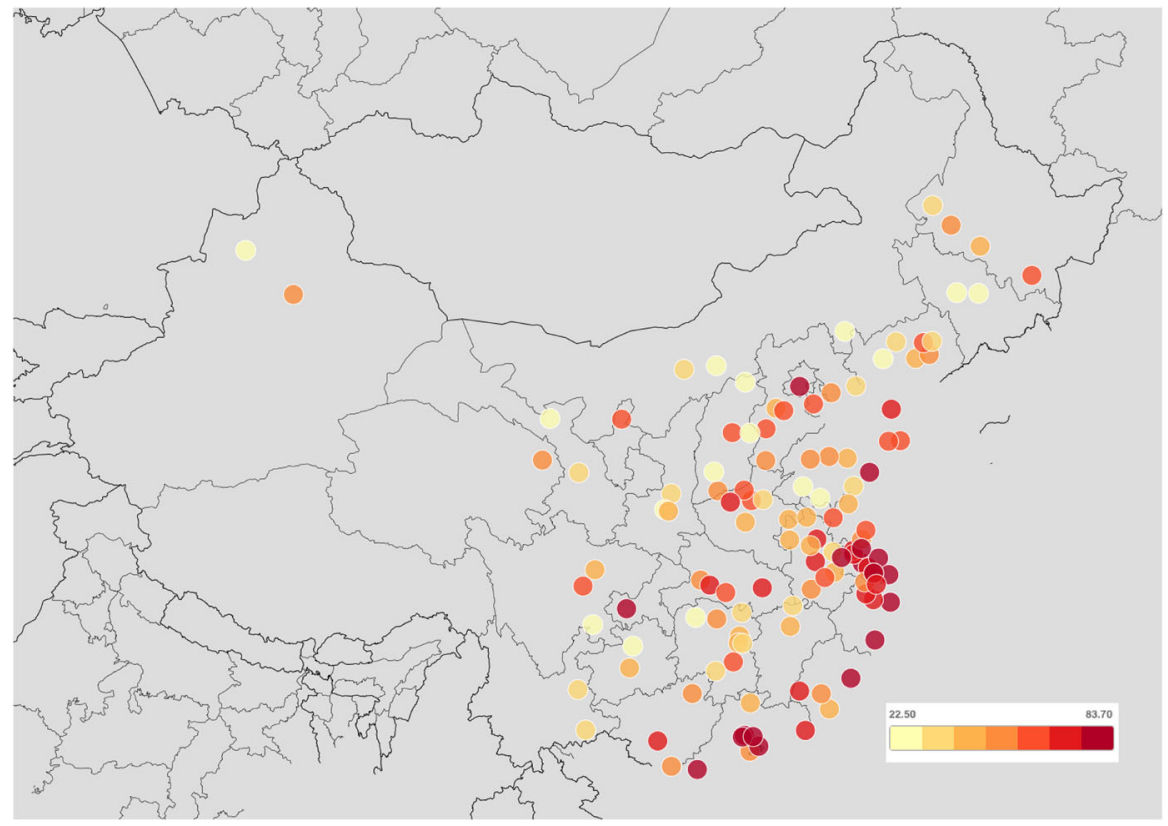

Fig. 3 Spatial pattern of PITI scores. Source: authors' map generated with data retrieved from http:// www.ipe.org.cn

\section{(a) Baseline variables}

China is a heterogeneous country in terms of economic development. Income levels between the East Coast, Central, and Western provinces have been diverging for many years (Song et al. 2000; Zhang and Zou 2012). Economic inequality at the county (Brehm 2013) and city level (Jones et al. 2003) are particularly pronounced. At the same time economic development represents one of the most decisive factors for a national or local government's commitment to promote a comprehensive environmental agenda. The Environmental Kuznets Curve (Grossman and Krueger 1991) represents a well-documented concept that establishes a connection between economic development and environmental protection. Several empirical studies on China confirm this claim (Dean et al. 2009; Bu et al. 2013; Shen 2008; Zhang and $\mathrm{Fu}$ 2008). We, therefore, use per capita gdp as a control variable in our baseline model. A second basic feature that varies substantially between Chinese cities is population size (Zhou and Sanderson 2013). Urbanization often poses challenges for environmental protection and the problems tend to increase with the size of a city (Shukla and Parikh 1992) a fact that empirical studies stress also for the case of China (Zhang et al. 2016; Tao et al. 2016; Han et al. 2016). We, therefore, use the number of a city's inhabitants as a second control variable in our baseline model. 


\section{(b) Fiscal variables}

Lorentzen et al. (2014) state that scoring high on the PITI is costly as it involves a row of tasks related to the collection, handling, and dissemination of data. In addition personnel costs increase since response to information requests need to be handled promptly and environmental supervision needs to become more comprehensive. This brings wealthy city governments in an advantageous position. We measure a municipality's fiscal capacity to implement environmental transparency regulations with the annual budgetary income and in addition with expenditures of a city's Environmental Protection Bureau.

(c) Economic variables

Disposing of the means to enforce environmental regulations and having the political will to do so are two different things. Ran (2013) provides an account of perverted incentive structures that fail to encourage local leaders to implement environmental laws. More recent revision of the cadre evaluation system seek to mitigate these shortcomings (Heberer and Trappel 2013) but the process continues to rely on one-dimensional prescriptions of quantitative targets without considering context and appropriateness of environmental measures (Kostka 2016). As a result environmental protection remains by and large subordinated to economic policies. In this context, it is reported, that promoting growth and attracting investments have been the most important criteria in responsibility contracts for leading cadres at the sub-provincial level (Edin 2003; Ong 2012; Landry et al. 2015). Thus, economic performance represents an important political career factor and at the same time creates the financial means needed for promoting environmental law enforcement. We seek to capture respective incentives with the annual gdp growth rate and per capita annual investments.

Besides these politicized economic indicators there is empirical evidence that the geographic concentration of manufacturing activity has a significant impact on compliance with environmental regulations (Zheng et al. 2014). To account for related structural differences we use the output share of the secondary sector as an additional control variable.

A number of well-documented large-scale environmental protests suggest that sometimes residents can force governments to back off from problematic investment projects (Deng and Yang 2013; Wu 2013) and this might also enhance political pressure to enhance environmental transparency. Yet protests and social resistance constitute idiosyncratic factors that are hard to grasp or measure systematically. To mitigate a potential omitted variable bias we include city-fixed effects in our estimations and decide upon the Hausman test (Table 3) whether this is a suitable specification. Summary statistics on our independent variables are provided in Table 2 . 
Table 2 Summary statistics (independent variables)

\begin{tabular}{lllllll}
\hline Variable & Unit & Obs & Mean & Std. Dev. & Min & Max \\
\hline GDP & Million Yuan & 371 & 37,380 & 24,407 & 55,150 & 175,125 \\
Population & 1000 Pers. & 365 & 4942 & 2653 & 742 & 14,171 \\
Environmental expenditure & RMB & 326 & 211.67 & 255.30 & 20.21 & 1613.03 \\
Budgetary income & $1000 \mathrm{RMB}$ & 370 & 220,290 & 380,524 & 10,078 & 320,687 \\
Output growth & Percent & 372 & 14.09 & 3.06 & 1.20 & 33.60 \\
Capital investment & 1000 RMB & 371 & 297,035 & 191,110 & 25,194 & $1,460,554$ \\
Secondary sector & Percent & 370 & 52.43 & 10.22 & 23.17 & 92.82 \\
\hline
\end{tabular}

\subsection{Data}

Our data originate from two sources: The PITI reports for the years 2009/2010, 2011, and 2012 available at the Institute of Public and Environmental Affairs (http:// www.ipe.org.cn/). Control variables are taken from various issues of China City Statistical Yearbook. We include all cities with a PITI score for the sample period. The dataset entails 110 key environmental protection cities with a politically proclaimed responsibility to take the lead in environmental affairs and transmit best practice to other cities. In addition, PITI reports list 18 prefecture-level municipalities that do not belong to the group of key environmental protection cities, but have great economic significance for their respective regions.

We motivate our variable selection with previous empirical findings. Yet there is a risk that the indicators selected are not relevant for the case at stake or constitute insufficient approximations due to uneven data quality or inconsistent indicator definitions. We, therefore, seek to achieve some quality assurance with a stepwise regression where the Akaike Information Criterion (AIC) in Table 4 determines whether a selected variable enhances the quality and explanatory power of the model and thus should be included. An additional problem arises from missing data. The descriptive statistics in Table 1 and 2 show that there are missing values in the range of $1.5-13 \%$ of total observation points. For spatial analyses, however, a panel has to be strongly balanced. Often missing values are set equal to zero, which, however, may distort results. To mitigate this issue we use multiple imputations (Rubin 1977, 2004). First we generate missing values randomly with a multivariate normal regression and generate ten complete data sets. The procedure to approximate the distribution of missing data is a Bayesian iterative Markov chain Monte Carlo approach. Spatial analysis is then performed on each of the ten imputed complete datasets. The final point estimates are averages of the parameter values generated by the ten imputations. Note that all estimates are retrieved from a $\log -\log$ function so that coefficients can be interpreted as elasticities. 


\section{Results}

\subsection{Model specification}

To investigate into the spatial properties of our data we follow the general to specific framework that LeSage and Pace (2009) consider the only appropriate approach. They argue that from a Bayesian model uncertainty perspective the analyst should estimate a SDM first because it represents a linear combination of a SAR and SEM. The SDM can be reduced to a SAR if $\theta=0$ and it can be collapsed into a SEM if $\theta=-\rho \beta$. Subsequently if a SAR/SEM specification suggests that $\rho=0$ or $\lambda=0$, respectively, then a simple OLS model will suffice to represent the case at stake (Elhorst 2010).

LeSage and Pace (2009, p. 74) posit that the SDM is superior to the SAR and SEM because it produces unbiased coefficients even in case of an omitted variable bias. Thus, if there is uncertainty about the true model a SDM should be used. We reject the null hypotheses $\theta=0$ for all model specifications and $\theta=-\rho \beta$ for 6 out of 8 cases (Table 3 ). To keep the results comparable we opted to estimate a SDM also for those cases where a SAR (model 3 and 4) appears to be sufficient.

The Hausman test (Table 3 ) rejects the hypothesis that the coefficients generated by a random effects estimator are not systematically different from a fixed effects estimator for all neighbourhood definitions. Thus, inclusion of city-fixed effects is required to mitigate a potential omitted variable bias.

\subsection{Variable selection}

In Table 4 (model 1-6) we present a stepwise regression based on an inverse distance matrix. Model 1 entails only basic controls, namely the level of economic development and city size approximated with per capita gdp and the number of inhabitants, respectively. Models 2 and 3 add fiscal indicators, which constitute a municipality's basic capacity to implement environmental regulations. In models 4-6 we account in addition for economic structure variables shaping political incentives and structural differences with a potential impact on environmental governance. The Akaike Information Criterion indicates that, among the fiscal indicators, only budgetary income enhances the quality of our model while

Table 3 LR and Hausman tests

\begin{tabular}{lccc}
\hline & $\theta=0$ & $-\rho \beta=\theta$ & Hausman \\
\hline Model 1 & $8.76^{\mathrm{c}}$ & $6.97^{\mathrm{b}}$ & $20.12^{\mathrm{a}}$ \\
Model 2 & $9.11^{\mathrm{b}}$ & $7.31^{\mathrm{c}}$ & $38.64^{\mathrm{a}}$ \\
Model 3 & $6.65^{\mathrm{c}}$ & 4.66 & $38.24^{\mathrm{a}}$ \\
Model 4 & $9.51^{\mathrm{b}}$ & 6.89 & $48.87^{\mathrm{a}}$ \\
Model 5 & $18.23^{\mathrm{a}}$ & $16.19^{\mathrm{a}}$ & $34.11^{\mathrm{a}}$ \\
Model 6 & $28.51^{\mathrm{a}}$ & $25.12^{\mathrm{a}}$ & $38.64^{\mathrm{a}}$ \\
Model 7 & $20.13^{\mathrm{a}}$ & $33.75^{\mathrm{a}}$ & $70.33^{\mathrm{a}}$ \\
Model 8 & $72.95^{\mathrm{a}}$ & $12.38^{\mathrm{a}}$ & $46.08^{\mathrm{a}}$ \\
\hline
\end{tabular}




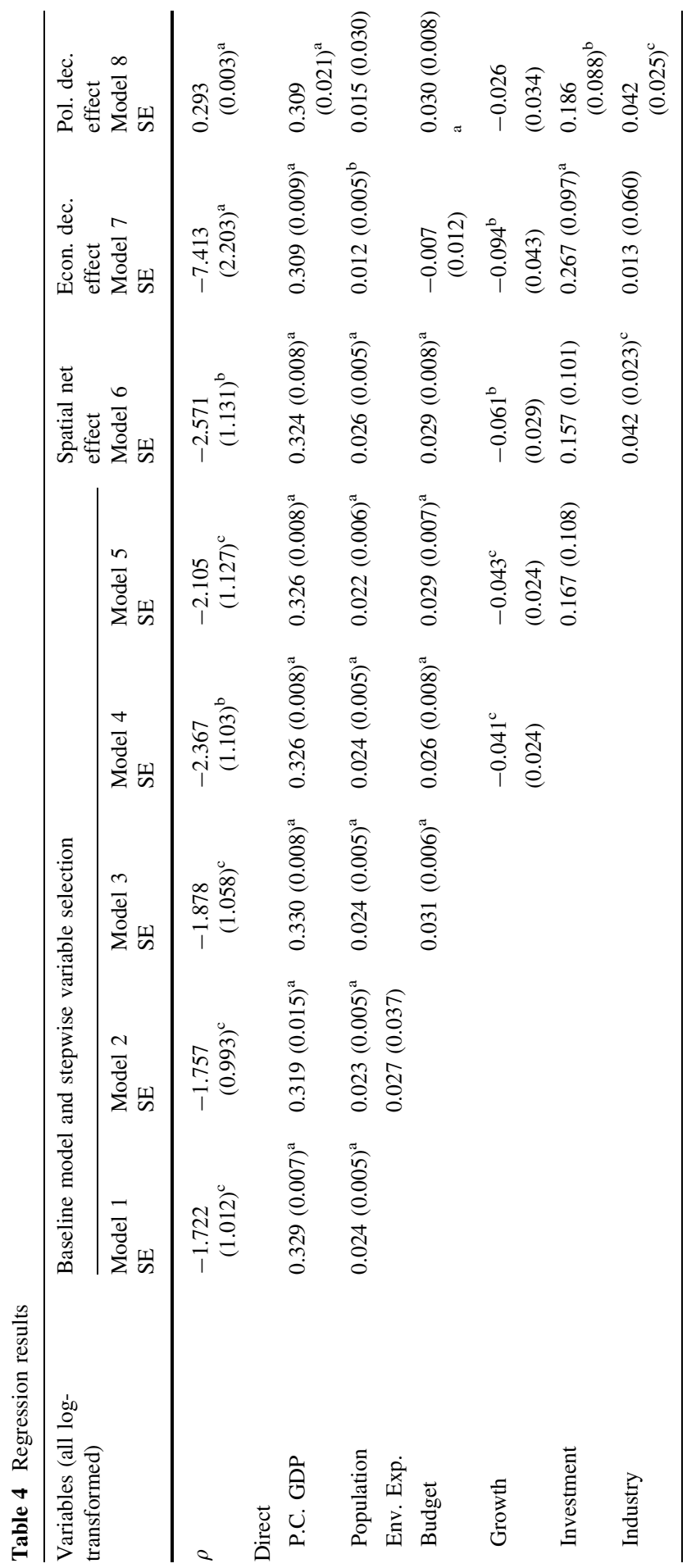




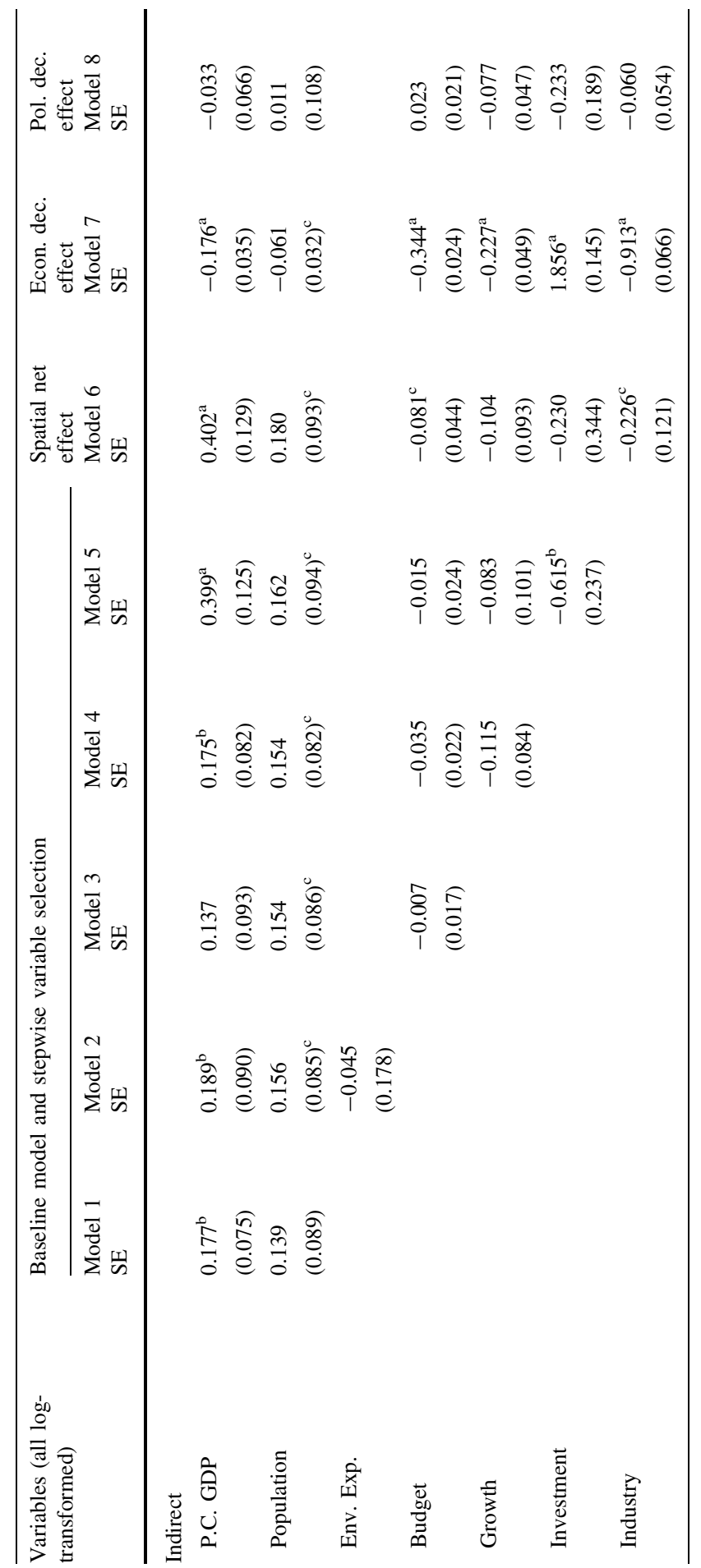




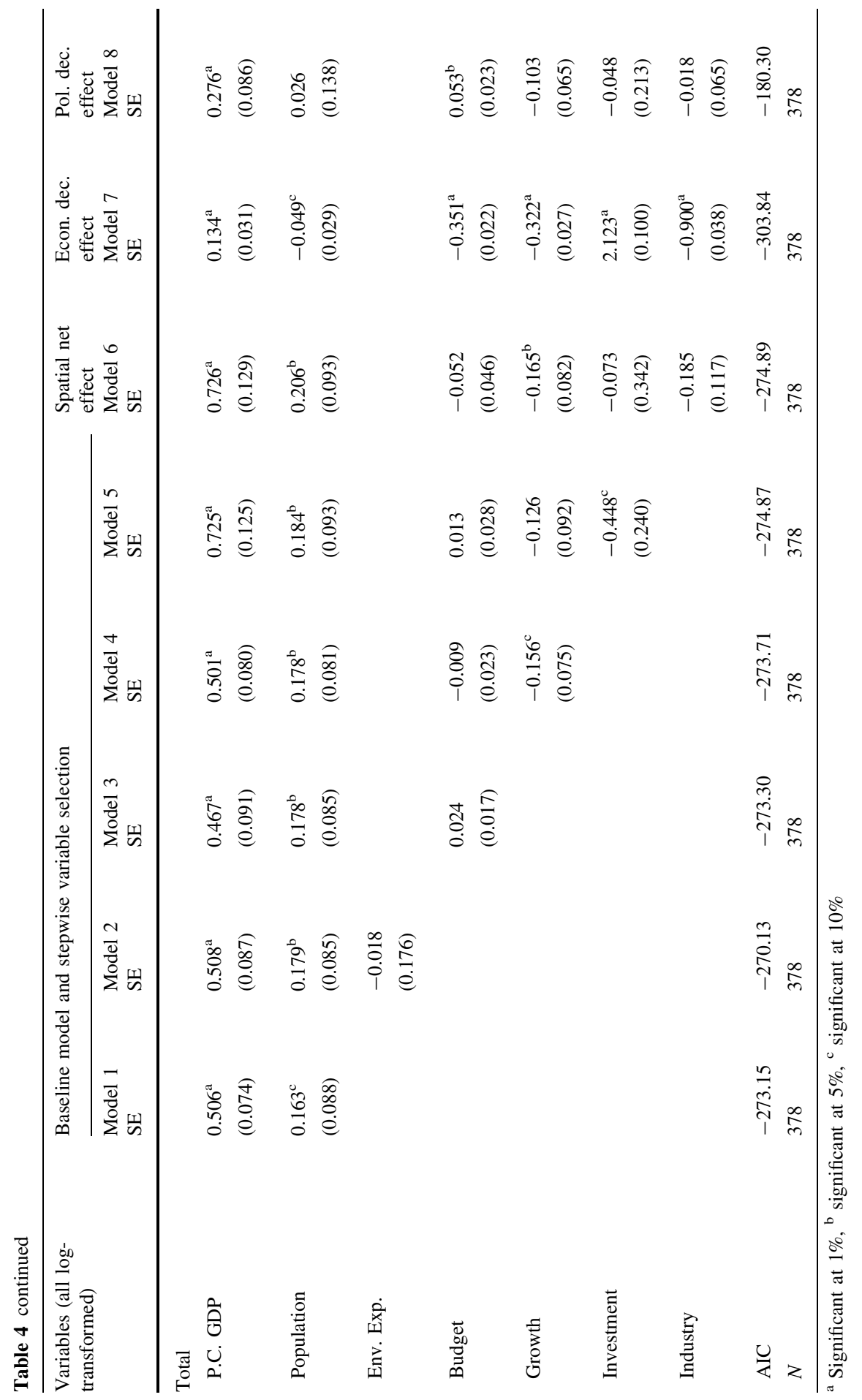


environmental expenditures result in an inferior specification. The inclusion of a quadratic term does not result in an improvement either. ${ }^{2}$ All economic structure variables improve model quality and unfold significant direct, indirect, or total effects (see Table 4).

\subsection{Estimation results}

The following analysis focuses on models $6-8$, where we look at the fully controlled model specification from three angles. In model 6 we use an inverse distance matrix to measure the net spatial effect, which might be positive (hypothesis 3a) or negative (hypothesis $3 b$ ). Model 7 is based on an economic distance matrix. This set-up provides insights whether or not Chinese cities belonging to the same income group promote comparable levels of environmental law enforcement (hypothesis 1a) or alternatively pursue strategic differentiation as a means to compete (hypothesis 1b). Finally in model 8 we measure the effect of political centralization with a province weight matrix. Given that provincial governments oversee environmental law implementation at the city level we would expect to find a trend towards convergence among urbanities subordinated to the same provincial administration (hypothesis 2).

The Akaike Information Criterion suggests that economic distance (model 7) provides the qualitatively best-suited specification. Yet, from an information theoretical point of view we cannot expect to find a single true model. Instead we aim for insightful or useful approximations (Burnham and Anderson 2004). From this perspective it makes sense to interpret each of the three models (models 6-8) in their own right because they reveal different sets of information.

(a) Spatial net effect

On a general note the inverse distance matrix results reveal a spatial pattern characterized by disintegration of environmental law enforcement levels. The spatial autocorrelation variable $\rho$ displays a negative sign and is significant at conventional levels for all specifications. In the fully controlled model (model 6 , Table 4) a municipality reduces its commitment to environmental law enforcement by $2.57 \%$ when transparency scores within a radius of $500 \mathrm{~km}$ increase by one $\% .^{3}$ This result confirms hypothesis $3 \mathrm{~b}$ and by extension implies an economic disintegration effect that is larger than a potential political centralization effect. We will look at respective outcomes in the following paragraph b., and c.

\footnotetext{
${ }^{2}$ We still deployed environmental expenditures in all subsequent model specifications and for all definitions of neighbourhood. Yet in none of the cases the variable turned out to be significant at conventional levels. Perhaps the definition of this budgetary item is too imprecise. On the one hand political discretion may lead to an overstatement of environmental expenditures when respective funds are used to nurture clientilist ties. On the other hand the measure may underrate environmental protection efforts because large projects such as the construction of sewage treatment plants or the introduction of energy-saving technologies are likely to be categorized as infrastructure or fixed capital investments.

${ }^{3}$ Note that we experimented with alternative distance bands starting at $100 \mathrm{~km}$, and then broadened it to 300 and eventually $500 \mathrm{~km}$. The spatial autocorrelation variable $\rho$ is insignificant but gradually approaches conventional significance levels at a threshold of about $500 \mathrm{~km}$.
} 
The direct effects of model 6 suggest that large cities with an advanced level of economic development, strong budgetary income sources, and a large industrial sector are most likely to enforce environmental regulations. In this context a $1 \%$ rise in gdp is associated with a $0.32 \%$ stronger PITI score. Economic development and city size of other municipalities unfold a positive indirect impact on environmental law enforcement with an average increase of 0.40 and $0.17 \%$, respectively. This gives reason to suppose that agglomeration effects are an important driver for raising the bar in environmental governance. At the same time, however, the negative sign for budgetary income and the secondary industry share imply that cities use free-riding strategies or compete with low environmental standards when other municipalities rely on a relatively well functioning industrial base. In the same vein, the total effects bring to the fore the consequences of "economic development first" policies. Here a $1 \%$ increase in economic growth results in a $0.17 \%$ PITI score decline.

To investigate further our claim that economic decentralization and political centralization represent opposing forces shaping spatial environmental governance patterns, we isolate the economic and political scale of spatial interaction with an economic and administrative distance matrix in the following paragraphs.

\section{(b) Economic decentralization effect}

In model 7 we define neighbourhood by gdp quartiles. The spatial autocorrelation variable $\rho$ turns out to be negative and significant at the one-percent level. The measured elasticity is $7.41 \%$ indicating that there is a quite strong Tiebout-sorting effect, i.e., when a city becomes more compliant with environmental transparency regulations other municipalities with a comparable development level will respond with relaxing their own enforcement efforts. Thus, we see hypothesis 1a confirmed.

The direct effects are similar to the inverse distance matrix results. Economic development, city size, and investments are positively correlated while growth unfolds a negative effect. The indirect effects bring to the fore economic differentiation as a major factor compromising a city's commitment to environmental transparency regulations. gdp, population, budgetary income, growth, and the industrial sector of municipalities with similar levels of economic development all have a negative influence on a city government's environmental commitments. On average a one $\%$ increase of these factors is associated with a $0.34 \%$ decline in terms of PITI scores. These results corroborate that cities with comparable economic endowments are competing with each other.

(c) Political centralization effect

In line with hypothesis 2 we find a significant positive spatial autocorrelation, i.e., convergence among cities under the same Provincial government (model 8). This demonstrates that political centralization and related coordination of political action along the horizontal command line indeed has the power to mitigate some of the divergence induced by a Tiebout sorting process. Yet the effect is quite small; $0.29 \%$ as opposed to the economic divergence effect of more than $7 \%$. Economic development, budgetary income, and investments unfold a significant positive direct 
effect on environmental law implementation. The elasticities of these factors are in the same range as in the inverse distance specification. Again the main difference is related to the indirect effects. In this case none of the variables is significant. That appears plausible given that coordination in this context is expected to evolve topdown and thus involves relatively little strategic interaction in between cities.

In sum the economic distance results confirm the presence of a Tiebout-sorting effect while the administrative distance outcomes suggest that political centralization imposes some constraints on this trend. For both cases direct effects are similar in size and have identical signs. In contrast to the administrative hierarchy results, indirect effects of the economic proximity matrix are in most cases significant. This supports our conjecture that economic decentralization rests on inter-city strategic interaction while political centralization establishes a top-down command line.

\section{Conclusion}

This study unveils some of the complex mechanisms shaping environmental law enforcement in China. The analysis takes into account that cities are ordered in an administrative and political hierarchy where each layer needs to be regarded as a distinct group with specific authorities and requirements. For the top-layer of this hierarchy we find that economic decentralization induces a trend towards diverging compliance levels while political centralization constrains local regulatory discretion.

Our empirical results give reason to suppose that the Chinese economy moved beyond homogenous preferences for low-cost regulatory arrangements. The emerging spatial pattern is in line with a Tiebout sorting process, where jurisdictions compete with diverse factor packages to attract an optimal number of constituents. Environmental regulation, however, is a Central Government task and hence local discretion remains limited. As a result the level of enforcement converges along China's horizontal command line from the Centre to Provinces. Our analysis suggests that high growth still is associated with relatively lax environmental law enforcement. Additionally, since many centrally assigned responsibilities remain unfunded, a city's fiscal capacity emerges as a crucial factor determining the level of environmental transparency law enforcement.

The here presented analysis includes only prefecture-level cities. Future research should also consider strategic response functions among county-level cities. In addition, more insights are needed to what extent the case of environmental transparency regulation is applicable to other realms of environmental law enforcement.

Open Access This article is distributed under the terms of the Creative Commons Attribution 4.0 International License (http://creativecommons.org/licenses/by/4.0/), which permits unrestricted use, distribution, and reproduction in any medium, provided you give appropriate credit to the original author(s) and the source, provide a link to the Creative Commons license, and indicate if changes were made. 


\section{References}

Anselin L (1988) Model validation in spatial econometrics: a review and evaluation of alternative approaches. Int Region Sci Rev 11(3):279-316

Antle JM, Heidebrink G (1995) Environment and development: theory and international evidence. Econ Dev Cult Chang 43(3):603-625

Blanchard O, Shleifer A (2001) Federalism with and without political centralization: China versus Russia. IMF staff papers 48(1):171-179

Boyd E, Folke C (2011) Adapting institutions: governance, complexity and social-ecological resilience. Cambridge University Press, Cambridge

Brehm S (2013) Fiscal incentives, public spending, and productivity-county-level evidence from a Chinese province. World Dev 46:92-103

Bu M, Liu Z, Wagner M, Yu X (2013) Corporate social responsibility and the pollution haven hypothesis: evidence from multinationals' investment decision in China. Asian Pac J Account Econ 20(1):85-99

Burnham KP, Anderson DR (2004) Multimodel inference: understanding AIC and BIC in model selection. Soc Methods Res 33(2):261-304

Cai H, Treisman D (2004) State corroding federalism. J Public Econ 88(3):819-843

Carter N, Mol AP (eds) (2013) Environmental governance in China. Routledge

Dean JM, Lovely ME, Wang H (2009) Are foreign investors attracted to weak environmental regulations? Evaluating the evidence from China. J Dev Econ 90(1):1-13

Deng Y, Yang G (2013) Pollution and protest in China: environmental mobilization in context. Chin Quart 214:321-336

Deng H, Zheng X, Huang N, Li F (2012) Strategic interaction in spending on environmental protection: spatial evidence from Chinese Cities. Chin World Econ 20(5):103-120

Edin M (2003) State capacity and local agent control in China: CCP cadre management from a township perspective. Chin Quart 173:35-52

Elhorst JP (2010) Applied spatial econometrics: raising the bar. Spat Econ Anal 5(1):9-28

Engel KH (1996) State environmental standard-setting: is there a race and is it to the bottom. Hastings LJ 48:271

Enikolopov R, Zhuravskaya E (2007) Decentralization and political institutions. J Public Econ 91(11):2261-2290

Feng X, Ljungwall C, Guo S, Wu AM (2013) Fiscal federalism: a refined theory and its application in the Chinese context. J Contemp Chin 22(82):573-593

Foster KW (2014) China and the environment: the green revolution. Pacific Aff 87(3):582-584

Geng Y, Fu J, Sarkis J, Xue B (2012) Towards a national circular economy indicator system in China: an evaluation and critical analysis. J Clean Product 23(1):216-224

Grossman GM, Krueger AB (1991) Environmental impacts of a North American free trade agreement (No. w3914). National Bureau of Economic Research

Han L, Zhou W, Pickett STA, Li W, Li L (2016) An optimum city size? The scaling relationship for urban population and fine particulate (PM2.5) concentration. Environ Pollut Part A 208:96-101

He G, Lu Y, Mol AP, Beckers T (2012) Changes and challenges: China's environmental management in transition. Environ Dev 3:25-38

Heberer T, Senz A (2011) Streamlining local behaviour through communication, incentives and control: a case study of local environmental policies in China. J Curr Chin Aff 40(3):77-112

Heberer T, Trappel R (2013) Evaluation processes, local cadres' behaviour and local development processes. J Contemp Chin 22(84):1048-1066

Jahiel AR (1997) The contradictory impact of reform on environmental protection in China. Chin Quart 149:81-103

Jahiel AR (1998) The organization of environmental protection in China. Chin Quart 156:757-787

Jin H, Qian Y, Weingast BR (2005) Regional decentralization and fiscal incentives: federalism, Chinese style. J Public Econ 89(9-10):1719-1742

Johnson T (2013) The health factor in anti-waste incinerator campaigns in Beijing and Guangzhou. Chin Quart 214:356-375

Jones DC, Li C, Owen AL (2003) Growth and regional inequality in China during the reform era. Chin Econ Rev 14(2):186-200

Kemp R, Soete L (1992) The greening of technological progress: an evolutionary perspective. Futures 24(5):437-457 
Kostka G (2016) Command without control: The case of China's environmental target system. Regul Govern 10(1):58-74

Kostka G, Mol AP (2013) Implementation and participation in China's local environmental politics: challenges and innovations. J Environ Plan Policy Manag 15(1):3-16

Landry PF, Lü X, Duan H (2015) Does performance matter? Evaluating political selection along the Chinese administrative ladder. In: Evaluating political selection along the Chinese Administrative Ladder (February 26, 2015). APSA 2014 Annual Meeting Paper, 2015

LeSage J, Pace RK (2009) Introduction to spatial econometrics. CRC Press, Bostan

Levinson A (2003) Environmental regulatory competition: a status report and some new evidence. Natl Tax J 56(1):91-106

Li W, Higgins P (2013) Controlling local environmental performance: an analysis of three national environmental management programs in the context of regional disparities in China. J Contemp Chin 22(81):409-427

Li Y-W, Miao B, Lang G (2011) The local environmental state in China: a study of county-level cities in Suzhou. Chin Quart 205:115-132

Lieberthal K, Oksenberg M (1988) Policy making in China: leaders, structures, and processes. Princeton University Press, Princeton

Liu N, Lo CW-H, Zhan X (2013) Collaborative governance and corporate environmental compliance in China. Conference Paper available at http://www.umdcipe.org/conferences/Government CollaborationShanghai/Submitted_Papers/Liu_Lo_Zhan_Paper.pdf. Accessed 26 Sept 2017

Lorentzen P, Landry P, Yasuda J (2014) Undermining authoritarian innovation: the power of China's industrial giants. J Polit 76(01):182-194

Montinola G, Qian Y, Weingast BR (1995) Federalism, Chinese style: the political basis for economic success in China. World Polit 48(01):50-81

Oates WE (1993) Fiscal decentralization and economic development. Natl Tax J 46(2):237-243

Oates WE, Schwab RM (1988) Economic competition among jurisdictions: efficiency enhancing or distortion inducing? J Public Econ 35(3):333-354

Olson M (1963) Rapid growth as a destabilizing force. J Econ Hist 23(04):529-552

Ong LH (2012) Fiscal federalism and soft budget constraints: the case of China. Int Polit Sci Rev 33(4):455-474

Qian Y, Weingast BR (1996) China's transition to markets: market-preserving federalism, Chinese style. J Policy Reform 1(2):149-185

Ran R (2013) Perverse incentive structure and policy implementation gap in China's local environmental politics. J Environ Plan Policy Manag 15(1):17-39

Richter WF (1994) The efficient allocation of local public factors in Tiebout's tradition. Region Sci Urban Econ 24(3):323-340

Rock MT (2002) Pathways to industrial environmental improvement in the East Asian newly industrializing economies. Business Strategy and the Environment 11(2):90-102

Rubin DB (1977) Subjective notions about the effect of nonrespondents in sample surveys. J Am Stat Assoc 72(359):538-543

Rubin DB (2004) Multiple imputation for nonresponse in surveys, vol 81. Wiley, Amsterdam

Shen J (2008) Trade liberalization and environmental degradation in China. Appl Econ 40(8):997-1004

Shukla V, Parikh K (1992) The environmental consequences of urban growth: cross-national perspectives on economic development, air pollution, and city size. Urban Geogr 13(5):422-449

Sigman H (2014) Decentralization and environmental quality: an international analysis of water pollution levels and variation. Land Econ 90(1):114-130

Song S, Chu GSF, Chao R (2000) Intercity regional disparity in China. Chin Econ Rev 11(3):246-261

Stern DI (2004) The rise and fall of the environmental Kuznets curve. World Dev 32(8):1419-1439

Stern DI, Common MS, Barbier EB (1996) Economic growth and environmental degradation: the environmental Kuznets curve and sustainable development. World Dev 24(7):1151-1160

Tao Y, Li F, Crittenden JC, Lu Z, Sun X (2016) Environmental impacts of China's urbanization from 2000 to 2010 and management implications. Environ Manag 57(2):498-507

Tester M, Langridge P (2010) Breeding technologies to increase crop production in a changing world. Science 327(5967):818-822

Tiebout CM (1956) A pure theory of local expenditures. J Polit Econ 64(5):416-424

Tobler WR (1970) A computer movie simulating urban growth in the Detroit region. Econ Geogr 46(sup1):234-240 
Tsang EY-H, Lee PK (2013) The Chinese new middle class and green NGOs in South China: Vanguards of Guanxi (connections)-seeking, laggards in promoting social causes? Chin Int J 11(2):155-169

Van Rooij B (2006) Implementation of Chinese environmental law: regular enforcement and political campaigns. Dev Chang 37(1):57-74

van Rooij B (2010) The people vs. pollution: understanding citizen action against pollution in China. J Contemp Chin 19(63):55-77

Van Rooij B, Lo CWH (2010) Fragile convergence: understanding variation in the enforcement of China's industrial pollution law. Law Policy 32(1):14-37

Wang A (2013) The search for sustainable legitimacy: environmental law and bureaucracy in China. Harvard Environ Law Rev 37:365-440

Weingast BR (2014) Second generation fiscal federalism: political aspects of decentralization and economic development. World Dev 53:14-25

Wellisch D (1995) Locational choices of firms and decentralized environmental policy with various instruments. J Urban Econ 37(3):290-310

Wong C, Bird R (2008) China's fiscal system: a work in progress. In: Brandt L, Rawski TG (eds) China's great economic transformation. Cambridge University Press, pp 429-466

Wu F (2013) Environmental activism in provincial China. J Environ Plan Policy Manag 15(1):89-108

Xie L (2011) China's environmental activism in the age of globalization. Asian Polit Policy 3(2):207-224

$\mathrm{Xu} \mathrm{C} \mathrm{(2011)} \mathrm{The} \mathrm{fundamental} \mathrm{institutions} \mathrm{of} \mathrm{China's} \mathrm{reforms} \mathrm{and} \mathrm{development.} \mathrm{J} \mathrm{Econ} \mathrm{Literat}$ 1076-1151

Zhang H, Wang Z, Zhang W (2016) Exploring spatiotemporal patterns of PM2.5 in China based on ground-level observations for 190 cities. Environ Pollut 216:559-567

Zhang X (2006) Fiscal decentralization and political centralization in China: implications for growth and inequality. J Compar Econ 34(4):713-726

Zhang J, Fu X (2008) FDI and environmental regulations in China. J Asia Pac Econ 13(3):332-353

Zhang Q, Zou H-F (2012) Regional inequality in contemporary China. Ann Econ Financ 13(1):113-137

Zheng S, Sun C, Qi Y, Kahn ME (2014) The evolving geography of China's industrial production: implications for pollution dynamics and urban quality of life. J Econ Surv 28(4):709-724

Zhou X, Sanderson H (2013) Chinese Anger over Pollution Becomes Main Cause of Social Unrest. Bloomberg News https://www.bloomberg.com/news/articles/2013-03-06/pollution-passes-landgrie vances-as-main-spark-of-china-protests . Accessed 16 Oct 2017

Zhou S, Dai J, Bu J (2013) City size distributions in China 1949 to 2010 and the impacts of government policies. Cities 32(Supplement 1):S51-S57

Zhuravskaya EV (2000) Incentives to provide local public goods: fiscal federalism, Russian style. J Public Econ 76(3):337-368 